\title{
PRESENTACIÓN
}

\section{Expresiones y sonidos de los pueblos}

$\mathrm{E}$ n la actualidad y en el ámbito de las antropologías y ciencias afines, cobran especial relevancia los estudios dedicados a la antropología de la música y la danza de las distintas culturas del mundo. La investigación que estudia el significado de la etnomusicología cuenta en el campo del conocimiento con un significativo acervo histórico y antropológico con obras que permiten diferenciar la diversidad y riqueza cultural de la música y los bailes de los pueblos. En esta ocasión, Desacatos, en su sección Saberes y Razones, abre sus páginas a diversos ensayos de investigadores, musicólogos y antropólogos dedicados no tan sólo al análisis de lo que ha sido y es la cultura musical y dancística de las sociedades en los distintos continentes del planeta, sino también, a difundir teorías y debates respecto al estudio de las expresiones y sonidos de los pueblos. La propuesta de Sergio Navarrete de agrupar ensayos de autores especialistas en el conocimiento de la música y la danza, así como de incorporar a este número un disco compacto con ejemplos de las músicas tradicionales estudiadas en los artículos, resulta interesante debido a que el conjunto permite recorrer un amplio espectro geográfico de manifestaciones rítmicas, melódicas y de combinación de sonidos que, algunas, en el transcurso de la historia y en pleno siglo XXI, permanecen en los modos de vida y costumbres de las civilizaciones.

El lector interesado en conocer las aportaciones que se han desarrollado en la antropología de la música podrá encontrar en el trabajo "Más allá del nacionalismo: trayectorias etnomusicológicas en Brasil" de Suzel Ana Reily, un recuento detallado sobre la evolución del estudio de la variada y rica música brasileña que destaca por su característico sincretismo cultural. El artículo "Antropología de la música en China: un estudio crítico", de Yang Mu, presenta un panorama enriquecedor sobre el enfoque nacionalista de la etnomusicología en China. Al mismo tiempo nos describe lo que ha sido la milenaria tradición del rescate musical por los estudiosos chinos. Mu nos presenta, además, un balance crítico de la situación que guardó la música de su país en tiempos de la "Revolución Cultural" y las políticas en torno a la disciplina que se han aplicado a lo largo de la segunda mitad del siglo XIX por el régimen encabezado por el Partido Comunista de China.

Miguel Olmos, en su ensayo "La etnomusicología en el norte de México", hace un repaso del surgimiento de la musicología mexicana. Destaca las influencias, las figuras precursoras y las instituciones que encauzaron los primeros estudios etnomusicológicos mexicanos. En la investigación sobre las peculiaridades de la música indígena en el noreste mexicano, Olmos realiza un análisis con valiosa información etnográfica que se desprende de las fiestas y rituales de los grupos indígenas mayos, guarijíos, pápagos, tarahumaras y seris.

En "'Brasilhana': la creación de un signo musical transcultural”, María Elizabeth Lucas centra su objeto de estudio en el regionalismo musical del estado de Río Grande do Soul, que cuenta con raíces hispano-europeas, pero que también recibe influencias luso-brasileñas. Lucas reconstruye en su trabajo, a partir de la presenta-

MARIO TRUjILlo Bolio: CIESAS-Oaxaca.

Desacatos, núm. 12, otoño 2003, pp. 7-8. 
ción de la canción "Brasilhana" en el marco de un festival de música nativista, la confrontación entre el esquema tradicional, marcador de la identidad gaucha/nativista y un nuevo flujo de revitalización cultural ya en curso en la década de 1980 en la que se sitúa el evento estudiado.

Larry Hilarian, a partir de un trabajo de campo y búsqueda minuciosa en escritos y fuentes primarias, retoma primero los orígenes del laúd para después centrarse en los antecedentes del gambus (laúd malayo) que es tradicionalmente ejecutado en la península de Malasia. En su artículo, Hilarian rastrea el recorrido histórico del instrumento a partir de la migración de persas y árabes al archipiélago malayo y la manera en que cobró vida y fue reintroducido, modificado y adaptado por músicos en Indonesia, Malasia y Singapur.

El ensayo de Adrienne L. Kaeppler, "La danza y el concepto de estilo", se ocupa en diferenciar la esencia, el referente cultural y estilístico del baile polinesio, que ha trascendido fronteras, conocido como hula pahu hawaiano. Los movimientos, la estructura, estilo, competencia y representación que constituyen el entorno de este baile son estudiados por Kaeppler para darnos una explicación puntual y detenida de esta representación dancística que forma parte esencial de la identidad cultural y étnica del pueblo polinesio. A través de ejemplos específicos, la autora desarrolla un concepto preciso de estilo, estrechamente relacionado con la estructura, la forma y el contenido social de cada danza en particular.

En la sección de Esquinas se presenta un tema de discusión planteado por el sociólogo francés Michel Wieviorka sobre los actuales retos de la investigación en las ciencias sociales. La importancia de las ideas expresadas por Wieviorka y el interés de las intervenciones de científicos sociales mexicanos surgidas durante la discusión llevó a que la revista Desacatos se diera a la tarea de presentar a sus lectores los distintos planteamientos que se desprenden del conocimiento antropológico y de las disciplinas sociales, con el propósito de promover la reflexión y el debate en la comunidad académica.

Sigue el artículo de Ángel Acuña Delgado, "Correr para vivir: el dilema rarámuri”, que es un estudio detenido del significado antropológico de la carrera de larga distancia y de resistencia practicada por los indígenas rarámuris de la Sierra Tarahumara. En su reseña etnográfica, Acuña delimita el significado de éstas en el espacio geográfico y cultural rarámuri, así como el componente socializante que se desprende de la competencia en la misma carrera.

En la sección de Testimonios publicamos un texto clásico de John Blacking titulado "¿Qué tan musical es el hombre?" Damos a conocer este trabajo en español con el propósito de presentar una de las investigaciones pioneras en los estudios etnomusicológicos en la que analiza la relación que establece con la música el pueblo venda del sur de África. La importancia del texto de Blacking radica precisamente en el enfoque metodológico seguido para comprender la cultura musical y dancística de los venda no a partir de la visión etnocentrista occidental sino más bien de un enfoque novedoso que permitió comprender los patrones de conducta de la producción de música y danzas de esta comunidad africana que aún mantiene sus tradiciones y cultura musical.

El ensayo de Brígida von Mentz, "Documentos en náhuatl en Cracovia", nos muestra la importancia que tiene la constante labor de investigación para rescatar y dar a conocer el acervo histórico de documentos coloniales que se encuentran en archivos y bibliotecas del extranjero. Con la pesquisa documental realizada por Von Mentz ahora es posible enriquecer con mayor información la historia demográfica de los pueblos de Morelos a partir de su hallazgo del censo náhuatl que se encuentra en la Biblioteca Jagiellowska de Polonia. Y, como bien dice en su artículo Von Mentz, con el censo en náhuatl ahora es posible confrontar este documento con otros códices valiosos que se encuentran en bibliotecas de Berlín, Francia y particularmente en la Biblioteca del Museo Nacional de Antropología e Historia. 